\title{
Estimating the population density of the Himalayan Rangeland weed Swertia ciliata (G. Don) Burtt.: An impact of topography and disturbance
}

\author{
Dil Kumar Limbu ${ }^{1 *}$ and Zhan-Huan Shang ${ }^{2}$ \\ ${ }^{1}$ Central Campus of Technology, T.U., Dharan, Nepal \\ ${ }^{2}$ International Centre for Tibetan Plateau Ecosystem Management, \\ Lanzhou University, China \\ *E-mail: dilklimbu@yahoo.com
}

\begin{abstract}
Swertia ciliata (G. Don) Burtt. is one of the most problematic weeds in the Himalayan rangelands. The main objective of this work is to assess the magnitude of $S$. ciliata invasion and analyze the impact of topographic factors and the disturbances on the distribution and population density. The work was conducted during August and September 2012 in the TinjureMilke mountain ridge at Gupha Pokhari, Nepal. The rangeland aspects (east, south and west) were considered the first level factor; and slopes ( $\leq 45$ degree and $\geq 45$ degree inclination) and the disturbance intensity were the second and third factors, respectively. Line transects made up $4 \mathrm{~m}^{2}, 74$ quadrats were laid down randomly to enumerate the weed population. The average population density of the $S$. ciliata was 127 plants $\mathrm{m}^{-2}$. The population density was found significantly different by the effects of the disturbances as well as aspects whereas the effect of the two slopes was found insignificant to the population density. A space is left for further research by ecological and edaphic factors. The study reveals that the infestation degree of $S$. ciliata is at a considerable level in the Himalayan rangeland and needs immediate control measures.
\end{abstract}

Key words: Gupha Pokhari, Tinjure-Milke-Jaljale, Weed population

\section{Introduction}

Rangeland weeds are unpalatable and unwanted native or alien invasive species that have an adverse impact on the forage by becoming dominant in grazed areas. At this moment most of the Himalayan rangeland weeds are native species (Limbu et al.,2012a). Rangeland weeds have a negative impact on the rangelands throughout the world because they reduce forage quality (Pike \& Stritzke, 1984; Cosgrove \& Barrett, 1987), displace desirable species, alter ecological processes, reduce wildlife habitats, degrade systems, decrease productivity and increase management costs associated with herbicide application and pasture restoration (DiTomaso, 2000; Masters \& Sheley, 2001).

Swertia ciliate (Family Gentianaceae) is an annual herb $20-100 \mathrm{~cm}$ tall, with quadrangular stems, sometimes branched. Leaves are opposite, sessile, narrowly ovate and pointed. Flowers are pale blue or bluish white with a purple band near the base above the gland (Noltie et al., 1994). It is locally called "Bhale chiraito". Usually, it is found between 2800 and $3800 \mathrm{~m}$ altitude and prefers a less disturbed open Himalayan rangeland. It is a serious weed of the Himalayan rangeland of Eastern Nepal. 
Research in weed population dynamics is very important for the design of effective and environmentally friendly weed control strategies as knowledge of weed density, seed production and seed bank establishment can be used to improved weed management (Navas, 1991; Liebman et al., 2001; Primot et al., 2006; Jasieniuk et al., 2008). Spatial distribution of plant species differs in place to place and various environmental (Anderson et al., 2003) and anthropogenic factors (Larson et al., 2001 cited in Limbu et al., 2012a) determine the distribution and population of weed species.

Numerous studies have been conducted on quantifying trends in weed population against different weed management practices. Notable quantification study of weeds has been done in crop field (Willinga et al., 1999; Arnaud et al., 2010; Vasileiadis, 2012) but less work in rangeland (Uygur et al., 2004; Limbu et al., 2012b).

The Himalayan rangelands are not well studied from the point of view of weed management and weed population estimation perspective. A lot of identification and management works on rangeland weeds have been carried out in developed countries, viz., Australia (Martin et al., 2006) and USA (DiTomaso et al., 2010). Rangelands cover $60 \%$ of the Hindu-Kush-Himalayan region (Shaoliang \& Sharma, 2009) but information on weeds' infestation sizes, density and impacts are unknown. Thus in this study we attempted to estimate the population density of $S$. ciliata and how influence the topographical factors (such as aspect and slope) influence the distribution and density of the weed.

\section{Materials and Methods Study area}

The research work was conducted in the Tinjure - Milke Mountain ridge and Gupha Pokhari area on the border of three districts, i.e., Taplejung, Tehrathum and Sankhuwasabha, $\left(27^{\circ} 09^{\prime} 30.5^{\prime \prime} \mathrm{N}\right.$ to $27^{\circ} 22^{\prime} 15^{\prime \prime} \mathrm{N}$ and $87^{\circ} 26^{\prime} 09^{\prime \prime} \mathrm{E}$ to $\left.87^{\circ} 34^{\prime} 14 " \mathrm{E}\right)$ of eastern Nepal (Fig. 1). The altitude of the study site ranges from $2650 \mathrm{~m}$ asl to $3400 \mathrm{~m}$ asl with an average temperature of $23^{\circ} \mathrm{C}$ and average annual rainfall of $2250 \mathrm{~mm}$. The region is grazed by livestock throughout the year because yaks and sheep are brought down to this area in the winter from the high Himalayan regions like Jaljale Mountain. Livestock raised in the study area are taken down to the low lands (1000 m to $1800 \mathrm{~m} \mathrm{msl})$ for grazing during the winter months. In the summer season, however, livestock movement is just the reverse. The Tinjure-Milke ridge and Gupha Pokhari area, thus, serves as a habitat corridor between Makalu-Barun Conservation Area and Kanchenjunga Conservation Area of Nepal. Both of conservation areas touch the Qomolongma Biosphere Reserve, Tibet (Koirala, 2002).

\section{Experimental design}

A stratified sampling procedure (Cochran, 1977) was used to collect data during August and September 2012. The experimental design incorporated three parameters, viz., slope, aspect and disturbance. We classified the slope of the rangeland into two categories. The first category includes slopes with an inclination less than 45 degree and the second with 45 degree or above. We considered three types of rangeland aspects, namely east, south and west. Two types of disturbance pattern were identified: the highly disturbed e.g., overgrazing, over trampling and the moderately disturbed area. We used a transect line method to enumerate the weeds in each sampling unit. Within each site, we randomly selected a point to begin vegetation sampling (without any prior knowledge of plant 
population at that point) and marked it. From the central sampling point, we established 40 $\mathrm{m}$ transect and placed $4 \mathrm{~m}^{2}(2 \mathrm{~m} \times 2 \mathrm{~m})$ quadrats at every $10 \mathrm{~m}$ intervals along this transect. A total of 74 sample quadrats were sampled in this study. Chi-square tests were employed by means of cross comparison to make sure whether our selection of the sample quadrats was biased or not.

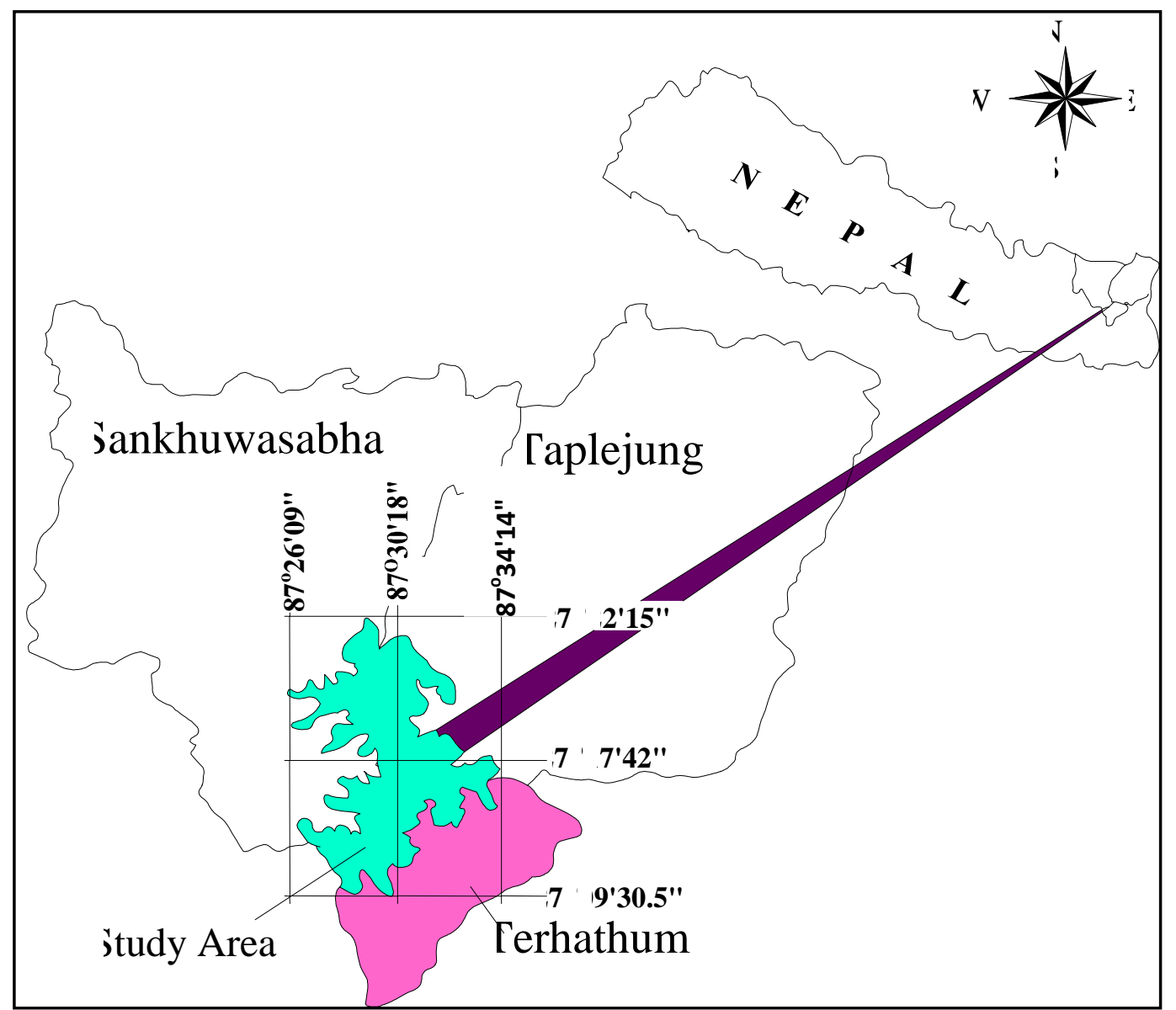

Figure 1. Map of Milke-Jaljale study area.

Test of independence for aspect, slope and disturbance were $\chi^{2}=1.546(\mathrm{p}=0.462), \chi^{2}=$ $0.365(\mathrm{p}=0.833)$ and $\chi^{2}=0.32(\mathrm{p}=0.57)$ respectively. All three Chi-squared tests concluded that our selections were not biased.

\section{Data collection and analysis}

All weeds enclosed by each quadrat were counted and the population density $\mathrm{m}^{-2}$ was calculated. The following formula was used to determine the population density of the weed in each quadrat:

$x_{r}=\frac{n_{r}}{A_{r}}$ 
Where, $x_{r}$ denotes the population density of the weed $\mathrm{m}^{-2}, n_{r}$ denotes the number of weeds (S. ciliata) in the $\mathrm{r}^{\text {th }}$ quadrat, $A$ denotes the area of each quadrat and $r=1,2, \ldots \ldots, 74$.

The average population density $\left(\mathrm{m}^{-2}\right)$ of the weeds in the study area was estimated by

$\bar{X}=\frac{1}{N} \sum_{r=1}^{N} x_{r}$

Where, $\mathrm{N}$ is the total number of chosen quadrats.

The formulae for the computation of the mean for the other factors of the study area were obtained similarly. All of the data analyses were carried out by using SPSS-20 (IBM-SPSS, 2011) software. To test whether there was a significant effect of the aspect, slope and disturbance of the rangeland on the population density of $S$. ciliata, we performed Univariate analysis of variance (UNIANOVA). ANOVA for general linear model was used to determine aspect, slope and disturbance effect on the single response variable population density. Treatment means obtained by ANOVA were compared using Tukey's HSD test at $\alpha=0.05$ level of significance.

\section{Results}

Statistical measures (mean \pm SE, $95 \%$ confidence interval for mean and the test statistics for significance) of the population densities of the weed were computed in different prospects of the rangeland. On the basis of observed mean in the studied rangeland, the overall weed density was $127 \pm 23$ (means \pm SD) $\mathrm{m}^{-2}$. Factor-wise, weed density was $136 \pm$ 30 (means $\pm \mathrm{SD}$ ) $\mathrm{m}^{-2}$ on east aspect, $129 \pm 25$ (means $\pm \mathrm{SD}$ ) $\mathrm{m}^{-2}$ on flat area and $139 \pm 24$ (means $\pm \mathrm{SD}) \mathrm{m}^{-2}$ on moderately disturbed area. The grand mean was $124 \pm 2$ (means $\pm \mathrm{SE}$ ) $\mathrm{m}^{-2}$ (Table 1).

Table 1. Population density of S. ciliata $\left(\mathrm{plant} / \mathrm{m}^{2}\right.$ ) at each level of three factors and condition of rangeland

\begin{tabular}{llccc}
\hline Factors/Levels & & Mean & Standard deviation (SD) & Number of samples (N) \\
\hline \multirow{3}{*}{ Aspect } & East & 136.06 & \pm 29.8 & 29 \\
& West & 113.7 & \pm 11.8 & 25 \\
\multirow{2}{*}{ Land inclination } & South & 129.76 & \pm 14.4 & 20 \\
& $\leq 45^{\circ}$ & 128.9 & \pm 24.8 & 52 \\
\multirow{2}{*}{ Disturbance } & High & 121.7 & \pm 18.2 & 22 \\
\hline Total & Moderate & 138.6 & \pm 13.4 & 35 \\
\hline
\end{tabular}

Whole model effect of aspect, slope and disturbance on the population of $S$. ciliata was determined by using univariate analysis of variance (UNIANOVA). The main effects of disturbance on weed density was highly significant such that less disturbance area had high weed density than high disturbance area $(F=17.67, \mathrm{p}=0.000)$ while weed density of inclined land and flat land were not significantly different $(F=1.79, p=1.85)$. Three levels of the aspect factor were significantly different among these. Tukey's HSD showed the west aspect of the rangeland had significantly less weed density than the other two aspects $(F=8.15, p=0.001)$ but east and south aspect was not significantly different $(p=0.42)$. Similarly, interaction effects of the different independent variables of the rangelands were 
computed. There was a significant interaction between aspect and slope $(F=4.526, p=$ $0.01)$. In eastern and western aspects, less inclined land had high weed density than more inclined rangeland $(F=5.72, p=0.02)$ and $(F=3.86, p=0.05)$ respectively. In southern aspect, land inclination had no effect $(F=2.56, p=0.1)$. Interaction between aspect and disturbance and disturbance and slope were not significant $(F=0.77, p=0.47)$ and $(F=$ $1.09, p=0.3$ ) respectively (Table 2 ). In eastern and southern aspects, moderately disturbed area had high weed density than highly disturbed rangeland $(F=13.26, p=0.01)$ and $(F=$ $4.22, p=0.04)$ respectively. In western aspect, disturbance had no effect $(\mathrm{F}=3.0, \mathrm{p}=0.08)$. Similarly in less inclined rangeland, moderately disturbed area had high weed density than highly disturbed rangeland $(F=23.54, p=0.00)$. In more inclined rangeland, disturbance had no effect $(F=3.54, p=0.07)$. The interaction between aspect, slope and disturbance did not effect on weed density $(F=0.067, p=0.93)$ (Table 2$)$.

Table 2. Whole-model effect of aspect, slope, disturbance and interactions on the population density of S. ciliata $\mathrm{m}^{-2}$.

\begin{tabular}{lllll}
\hline Parameter & Df & MS & F & P. \\
\hline Main effects & & & & \\
Corrected Model & 11 & 1928.25 & 6.683 & 0.000 \\
Intercept & 1 & 878600.06 & 3044.97 & 0.000 \\
Aspect & 2 & 2353.5 & 8.157 & 0.001 \\
Slope & 1 & 518.15 & 1.796 & NS \\
Disturbance & 1 & 5100.6 & 17.677 & 0.000 \\
\hline Interaction effects & & & & \\
Aspect $\times$ Slope & 2 & 1305.8 & 4.526 & 0.015 \\
Aspect $\times$ Disturbance & 2 & 221.6 & 0.768 & NS \\
Slope $\times$ Disturbance & 1 & 312.95 & 1.085 & NS \\
Aspect $\times$ Slope $\times$ Disturbance & 2 & 19.34 & 0.067 & NS \\
Error & 62 & 288.54 & & \\
\hline Total & 74 & & & \\
\hline
\end{tabular}

Homogeneity test based on the observed mean provides the information that the average population density of the east and south aspect is homogeneous.

Leven's test was used for the tests of equality of error variance of the dependent variable across all the groups (different aspects of the rangeland). It was found that there is no equality of the variance of the weed density in all aspects of the rangeland $(F=5.404, P=$ $0.000)$.

\section{Discussion}

Distribution of rangeland weed, S. ciliata, was significantly influenced by disturbance but land inclination was insignificant. Similarly the population density of $S$. ciliata in the southern aspect was different than eastern and western aspect of rangeland. In addition soil $\mathrm{pH}$, nutrient and age of rangeland drive the weed distribution. However some research results reveal that distribution of Swertia sp. is not uniform; it depends upon the altitude and slope. It was higher population density on north facing sloppiness than fattened area. It prefers to grow in acidic soil condition with $\mathrm{pH}$ of 4.7 to 5.5 in association with other 
species like Fragaria indica, Anaphilis triplinervis, Cynodon dactylon and Digitaria adecendens (Bhattarai \& Shrestha, 1996).

Limbu et al. (2012a) have reported 30 plants $\mathrm{m}^{-2}$ density of Senecio chrysamthemoides, a problematic Himalayan rangeland weed in Milke-Jaljale area. The present work shows the density of $S$. ciliata is much greater than that of the former species. It is more problematic to the rangelands. Fowler (2002) pointed out that some plant species prefer to grow on slope and other on flat land, but Fowler's observation is falsified by this study, which shows the population density of $S$. ciliata is not affected much by the slope of the land. The finding of the present study was in agreement with McIntyre et al. (1995) observation that intensive grazing (disturbance) can result in reductions in native plant species' richness.

Vegetation distribution is influenced by various factors. The spatial distribution, pattern and abundance of plant species in a rangeland have often been related to three groups of factors: physical environmental variables, soil chemistry and anthropogenic disturbances (Enright et al., 2005). A disturbance could act as a strong selective force on plant species traits (Denslow, 1980; Miao \& Bazzaz, 1990) allowing particular species to tolerate or even take advantage of specific environmental changes due to a disturbance (Martinsen et al., 1990; McIntyre et al., 1995). Disturbances may have positive effects on some plant species, but negative when the disturbance is extensive, resulting in bare soil patches (Austrheim \& Eriksson, 2001; Klug et al., 2002; Cairns \& Moen, 2004; Olofsson et al., 2005).

Vegetation distribution is also affected by topographical factors (Kingston \& Waldren, 2003; Sebastia, 2004). Topographic characteristics like elevation, slope and aspect are closely associated with local climate (e.g., precipitation, evaporation and solar incident radiation) that have a great impacts on plants (Davies et al., 2007). Topographic characteristics regulate seed, water and nutrient redistribution, thereby impacting plants distribution pattern (Parker, 1982; Pinder et al., 1997; Canton et al., 2004; Fu et al., 2004). Upland (slope) and lowland (flat) areas have different impacts on plant distribution (Hook $\&$ Burke, 2000). Due to erosion and cattle movement, surface soil, humus and plant's seed from upland move down to lowland and are deposited there. Thus lowland plots are enriched with silt, clay, carbon and nitrogen relative to adjacent upland plots. Cattle graze lowlands preferentially (Senft et al., 1985; Milchunas et al., 1989). As a result, plants luxuriantly grow on lowland compare to upland. Similarly forage is grazed by cattle but weed plants are left.

This work has addressed only a handful of factors (disturbance, slope and aspect of rangeland) that affect the distribution and population of the weed, S. ciliata, in the high altitude Himalayan rangeland, i. e. in our study area. Further research will address the remaining factors and predict the population density of weed precisely and reveal the population growth projection of the Himalayan rangeland.

\section{Conclusion}

The estimation of density of the $S$. ciliata is very important for weed management strategy in rangelands. A weed, with about $60 \mathrm{~cm}$ height, having the population density of 127 plants $/ \mathrm{m}^{2}$ on a rangeland is a serious threat to the rangeland quality and management. It needs some control measures immediately to arrest further infestation. Notable disturbance 
(grazing and trampling) regulates infestation and distribution of weed, S. ciliata, on rangeland. Aspect and disturbance appear more influential factors than slope for determining the distribution of S. ciliata. In addition, there are other more influencing factors i.e. ecological and edaphic for the spatial distribution and infestation of the weed.

\section{Acknowledgements}

The authors wish to thank informants and the herdsmen for nature and history of study area, Tinjure-Milke. We thank the Menchyayam Community Forest user group, Tehrathum for permitted us to study. We extend our thanks to Mr. J.B. Limbu, Mr. R. Bhattarai and Mr. P. Sherpa for field work assistance. We particularly thank K.R. Rajbhandari for identification of weed plant. The first author is grateful to the University Grants Commission, Nepal for the research fellowship.

\section{References}

Anderson, R.P., D. Lew \& A.T. Peterson 2003. Evaluating predictive models of species' distributions: criteria for selecting optimal models. Ecological Modelling 162: 211-232.

Arnaud, J.-F., S. Fe'nart, M. Cordellier \& J. Cuguen 2010. Populations of weedy crop-wild hybrid beets show contrasting variation in mating system and population genetic structure. Evol. Appl. 3: 305-318.

Austrheim, G. \& O. Eriksson 2001. Plant species diversity and grazing in the Scandinavian mountains patterns and processes at different spatial scales. Ecography 24: 683-695.

Bhattarai, K.R. \& K. Shrestha 1996. Ecology study on Chiraito in Northern Gorkha. J. Nat. Hist. Mus. 15: 13-16.

Cairns, D.M. \& J.O.N. Moen 2004. Herbivory influences tree lines. Journal of Ecology 92: 1019-1024.

Cantón, Y., G. Del Barrio, A. Solé-Benet \& R. Lázaro 2004. Topographic controls on the spatial distribution of ground cover in the Tabernas badlands of SE Spain. Catena 55: 341-365.

Cochran, W.G. 1977. Sampling techniques ( $3^{\text {rd }}$ ed). John Wiley and Sons, New York.

Cosgrove, D.R. \& M. Barrett 1987. Effects of weed control in established alfalfa (Medicago sativa) on forage yield and quality. Weed Science 35: 564-567.

Davies, K.W., J.D. Bates \& R.F. Miller 2007. Environmental and vegetation relationships of the Artemisia tridentata spp. wyomingensis alliance. Journal of Arid Environments 70: 478494.

Denslow, J.S. 1980. Gap partitioning among tropical rainforest trees. Biotropica 12: 47-55.

DiTomaso, J.M. 2000. Invasive weeds in rangelands: species, impacts, and management. Weed Sci. 48: 255-265.

DiTomaso, J.M., R.A. Masters \& V.F. Peterson 2010. Rangeland invasive plant management. Rangelands 32: 43-47.

Enright, N.J., B.P. Miller \& R. Akhter 2005. Desert vegetation and vegetation-environment relationships in Kirthar National Park, Sindh, Pakistan. Journal of Arid Environments 61: 397-418.

Fowler, N.L. 2002. The joint effects of grazing, competition and topographic position on six savanna grasses. Ecology 83: 2477-2488. 
Fu, B.J., S.L. Liu, K.M. Ma \& Y.G. Zhu 2004. Relationships between soil characteristics, topography and plant diversity in a heterogeneous deciduous broad-leaved forest near Beijing, China. Plant and soil 261: 47-54.

Hook, P.B. \& I.C. Burke 2000. Biogeohemistry in a shortgrass landscape: Control by topography, soil texture, and microclimate. Ecology 81: 2686-2703.

IBM-SPSS 2011. IBM SPSS Statistics for Windows, version 20.0. Armonk, IBM Corp, NY.

Jasieniuk, M., M.L. Taper, N.C. Wagner, R.N. Stougaard, M. Brelsford \& B.D. Maxwell 2008. Selection of a barley yield model using information-theoretic criteria. Weed Science 56: 628-636.

Kingston, N. \& S. Waldren 2003. The plant communities and environmental gradients of Pitcairn Island: the significance of invasive species and the need for conservation management. Annals of Botany 92: 31-40.

Klug, B., G. Scharfetter-Lehrl \& E. Scharfetter 2002. Effects of trampling on vegetation above the timberline in the Eastern Alps, Austria. Arctic, antarctic, and alpine research 34: 377-388.

Koirala, M. 2002. Environmental determinants of the livelihood related food production system in a Mid-Himalayan landscape (Tinjure-Milke region), East Nepal. In: Environmental Science. Jawaharlal Nehru University, New Delhi, India.

Larson, D.L., P.J. Anderson \& W. Newton 2001. Alien plant invasion in mixed-grass prairie: effects of vegetation type and anthropogenic disturbance. Ecological Applications 11: 128-141.

Liebman, M., C.L. Mohler \& C.P. Staver 2001. Ecological management of agricultural weeds. Cambridge University Press, Cambridge.

Limbu, D.K., M. Koirala \& Z. Shang 2012b. A survey of Himalayan rangeland weeds in Tinjure-Milke-Jaljale area. Nepalese Journal of Biosciences 2: 24-30.

Limbu, D.K., R.P. Khatiwada, M. Koirala \& Z. Shang 2012a. Estimating population density of Himalayan rangeland weed Senecio chrysamthemoides DC. Our Nature 10: 1-7.

Martin, T.G., S. Campbell \& S. Grounds 2006. Weeds of Australian rangelands. The Rangeland Journal 28: 3-26.

Martinsen, G.D., J.H. Cushman \& T.G. Whitman 1990. Impact of pocket gopher disturbance on plant species diversity in a shortgrass prairie community. Oecologia 83: 132-138.

Masters, R.A. \& R.L. Sheley 2001. Principles and practices for managing rangeland invasive plants. J. Range Manag 54: 502-517.

McIntyre, S., S. Lavorel \& R.M. Tremont 1995. Plant life-history attributes: their relationship to disturbance response in herbaceous vegetation. Journal of Ecology 83: 31-44.

Miao, S.L. \& F.A. Bazzaz 1990. Responses to nutrient pulses of two colonizers requiring different disturbance frequencies. Ecology 71: 2166-2178.

Milchunas, D.G., W.K. Lauenroth, P.L. Chapman \& M.K. Kazempour 1989. Effects of grazing, topography, and precipitation on the structure of a semiarid grassland. Vegetatio 80: 1123.

Navas, M.L. 1991. Using plant population biology in weed research: a strategy to improve weed management. Weed Research 31: 171-179.

Noltie, H. J. 1994. Flora of Bhutan. Royal Botanical Gardens. 
Olofsson, J., P.E. Hulme, L. Oksanen \& O. Suominen 2005. Effects of mammalian herbivores on revegetation of disturbed areas in the forest-tundra ecotone in northern Fennoscandia. Landscape ecology 20: 351-359.

Parker, A.J. 1982. The topographic relative moisture index: an approach to soil-moisture assessment in mountain terrain. Physical Geography 3: 160-168.

Pike, D.R. \& J.F. Stritzke 1984. Alfalfa (Medicago sativa) - cheat (Bromus secalinus) competition. Weed Science 32: 751-756.

Pinder, J.E., G.C. Kroh, J.D. White \& A.M. Basham 1997. The relationships between vegetation type and topography in Lassen Volcanic National Park. Plant ecology 131: 17-29.

Primot, S., M. Valantin-Morison \& D. Makowski 2006. Predicting the risk of weed infestation in winter oilseed rape crops. Weed Research 46: 22-33.

Sebastiá, M.T. 2004. Role of topography and soils in grassland structuring at the landscape and community scales. Basic and Applied Ecology 5: 331-346.

Senft, R.L., L.R. Rittenhouse \& R.G. Woodmansee 1985. Factors influencing patterns of cattle grazing behavior on shortgrass steppe. Journal of Range Management 38: 82-87.

Shaoliang, Y. \& E. Sharma 2009. Climate change and the Hindu Kush-Himalayan rangeland information. In: International Centre for Integrated Mountain Development (ICIMOD). Kathmandu, Nepal.

Uygur, S., L. Smith, F.N. Uygur, M. Cristofaro \& J. Balciunas 2004. Population densities of yellow starthistle (Centaurea solstitialis) in Turkey. Weed Science 52: 746-753.

Vasileiadis, V.P., R.J. Froud-williams \& I.G. Eleftherohorinos 2012. Tillage and herbicide treatments with inter-row cultivation influence weed densities and yield of three industrial crops. Weed Biology and Management 12: 84-90.

Willinga, J., J. Grasman, R.M.W. Groeneveld, M.J. Kropff \& L.A.P. Lotz 1999. Prediction of weed density: the increase of error with prediction interval, and the use of long-term prediction for weed management. Journal of Applied Ecology 36: 307-316. 